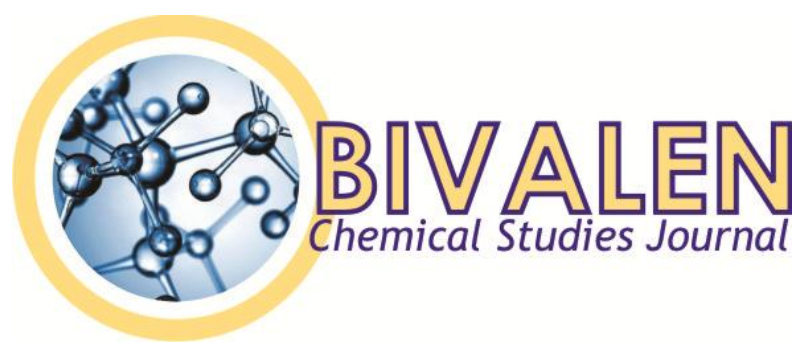

\title{
HASIL BELAJAR SISWA SMA YANG DIAJAR MENGGUNAKAN MODEL PEMBELAJARAN EKPA DAN POE PADA POKOK BAHASAN LARUTAN ELEKTROLIT DAN NONELEKTROLIT
}

\section{LEARNING OUTCOMES OF SENIOR HIGH SCHOOL STUDENT TAUGHT USING EKPA AND POE LEARNING MODELS ON THE SUBJECT OF ELECTROLYTE AND NONELEKTROLYTE SOLUTIONS}

\author{
Siska Wardani", Muflihah, Maasje C. Watulingas \\ Program Studi Sarjana Pendidikan Kimia Fakultas Keguruan dan Ilmu Pendidikan, Universitas Mulawarman, \\ Samarinda, Kalimantan Timur, Indonesia \\ *Corresponding Author: siskawardani19@gmail.com(+6282231108268)
}

\begin{abstract}
ABSTRAK
Penelitian ini bertujuan untuk mengetahui perbedaan antara hasil belajar siswa SMA yang diajar dengan menggunakan model pembelajaran EKPA (Elisitasi, Konfrontasi, Pengembangan konsep, Aplikasi konsep) dan model pembelajaran POE (Predict, Observe, Explain) pada sub pokok bahasan larutan elektrolit dan nonelektrolit. Penelitian ini dilaksanakan di SMA Negeri 9 Samarinda, Indonesia, pada tahun ajaran 2016/2017. Subjek penelitian adalah siswa kelas X $\mathrm{IPA}_{1}$ dan X IPA $\mathrm{A}_{2}$ dengan masing-masing kelas berjumlah 30 siswa. Subjek penelitian dipilih menggunakan teknik purposive sampling. Siswa kelas $\mathrm{X} \mathrm{IPA}_{1}$ diajarkan dengan menggunakan model pembelajaran EKPA dan siswa kelas $\mathrm{X} \quad \mathrm{IPA}_{2}$ diajarkan menggunakan model pembelajaran POE. Hasil penelitian menunjukkan bahwa tidak terdapat perbedaan hasil belajar kimia antara siswa SMA yang diajar dengan model pembelajaran EKPA dengan model pembelajaran POE pada sub pokok bahasan larutan elektrolit dan nonelektrolit.
\end{abstract}

Kata kunci: hasil belajar, model pembelajaran EKPA dan POE, elektrolit, Nonelektrolit

\begin{abstract}
This research aimed to know the difference between senior high school student learning outcomes taught using EKPA (elisitasi, konfrontasi, pengembangan konsep, aplikasi konsep) and POE (predict, observe, explain) learning models on the subject of electrolyte and nonelectrolyte solutions. This research was conducted at SMA Negeri 9 Samarinda, Indonesia, in academic year of 2016/2017. Subjects of this research were students of eleventh grade, called as students of X IPA 1 and X IPA 2 classes/groups: each group consisted of 30 students. The subjects were selected using purposive sampling. Student of $\mathrm{X} \mathrm{IPA}_{1}$ taught using EKPA learning model and students of $\mathrm{X} \mathrm{IPA}_{2}$ taught using POE learning model. The results showed that subject of electrolyte and nonelectrolyte solutions were not difference.
\end{abstract}

Keywords: learning outcomes, EKPA and POE learning models, electrolyte, nonelectrolyte 


\section{PENDAHULUAN}

Pengetahuan awal adalah hal yang penting dalam membangun pengetahuan baru. Pengetahuan awal berperan dalam membuat atau merekontruksi pengetahuan baru sehingga pengetahuan awal ini tidak boleh diabaikan oleh seorang guru (Riyanro, 2011). Seorang guru harus mempertimbangkan pengetahuan awal siswa dalam menetapkan metode dan atau model pembelajaran yang akan digunakan (Lesatri, 2012).

Salah satu model pembelajaran yang dapat mempertimbangkan pengetahuan awal siswa atau model pembelajaran yang dikembangkan berdasarkan pandangan konstruktivisme adalah model pembelajaran EKPA (Elisitasi, Konfrontasi, Pengembangan konsep, Aplikasi konsep). Dalam fase-fase model pembelajaran EKPA terdapat kegiatan mengkontradiktif fenomena dengan gagasan siswa, sehingga pembelajaran akan lebih efektif, pengetahuan siswa cepat terserap bertahan lama dalam memori siswa dan siswa tidak mengalami kebingungan antara pengetahuan awal yang mereka miliki dengan teori yang sebenarnya. Berdasarkan penelitian Nurachman (2014), penggunaan model pembelajaran EKPA dapat meningkatkan hasil belajar siswa.

Model pembelajaran lain yang juga dikembangkan berdasarkan pandangan konstruktivisme adalah model pembelajaran POE (predict, observe, explain). Pada langkah pembelajaran POE, terdapat tahap dimana siswa memprediksikan jawaban dari suatu permasalah kemudian menyusun dugaan awal berdasarkan pengetahuan awal yang mereka miliki, hasil penelitian Farikha (2015), penerapan model pembelajaran POE disertai eksperimen pada materi hidrolisis garam dapat meningkatkan aktifitas belajar siswa.

Pada kedua model pembelajaran yang disebut di atas, dalam proses pembelajarannya siswa menggali dan mengeksplorasi pengetahuan awal yang dimiliki dan mengkonstruksikannya dengan materi pembelajaran. Kedua model pembelajaran ini memiliki tahapan yang berbeda namun dalam proses pembelajarannya sama yaitu sama-sama membuat hipotesis atau jawaban sementara dari suatu permasalahan dan membuktikannya melalui kegiatan praktikum, sehingga nantinya siswa akan mengetahui apakah hipotesis yang telah mereka buat sudah benar atau sebaliknya.
Sebagai mata pelajaran yang tidak terlepas dengan eksperimen (praktikum). Kimia merupakan mata pelajaran yang cocok dalam penerapan model pembelajaran yang berbasis konstruktivisme. Salah satu pokok bahasan dalam mata pelajaran kimia yang melibatkan eksperimen adalah larutan elektrolit dan nonelektrolit. Berdasarkan uraian di atas, penulis melakukan penelitian untuk mengetahui perbedaan hasil belajar kimi siswa SMA yang di ajar menggunakan model pembelajaran EKPA dan model pembelajaran POE pada sub pokok bahasan larutan elektrolit dan nonelektrolit.

\section{METODE PENELITIAN}

Penelitian ini dilaksanakan di SMA Negeri 9 Samarinda, Kalimantan Timur, Indonesia pada tahun ajaran 2016/2017. Jenis penelitian ini tergolong penelitian eksperimental. Subjek dalam penelitian ini adalah siswa kelas $\mathrm{X} \mathrm{IPA}_{1}$ yang diajar dengan menggunakan model pembelajaran EKPA dan siswa kelas $\mathrm{IPA}_{2}$ yang diajar menggunakan model pembelajaran POE. Kedua kelas dipilih menggunakan teknik purposive sampling. Masingmasing kelas terdiri atas 30 siswa. Penelitian ini berlangsung selama tiga kali pertemuan. Pada pertemuan pertama dan kedua siswa diajar menggunakan model pembelajaran sesuai dengan kelas masing-masing yang telah ditentukan dan pada setiap akhir pembelajaran diberikan post-test. Pertemuan ketiga berupa ulangan harian. Data dalam penelitian ini berupa data hasil belajar siswa sebelum dan sesudah diberi perlakuan dan aktivitas siswa selama proses pembelajaran. Data hasil belajar siswa sebelumnya digunakan untuk mengetahui homogenitas subjek penelitian, sedangkan data hasil belajar siswa setelah diajar menggunakan model pembelajaran EKPA dan POE diperoleh dari masing-masing $30 \%$ nilai post-test dan $40 \%$ nilai ulangan harian. Data aktivitas siswa diperoleh melalui observasi. Soal post-test, soal ulangan harian dan lembar observasi divalidasi oleh dosen program studi S-1 pendidikan kimia, FKIP, Universitas Mulawarman. Perbedaan hasil belajar siswa dianalisis menggunakan uji $t(\alpha=0,05)$.

\section{HASIL DAN PEMBAHASAN}

Pembelajaran pada kedua kelas di awali dengan mengkondisikan siswa agar siap untuk memulai aktivitas belajar. Kedua kelas diberikan pembelajaran dengan kegiatan mengamati gambar, membuat hipotesis, dan kegiatan praktikum. Pada kelas yang diajar dengan model pembelajaran EKPA, siswa diminta mengamati beberapa gambar 
yang tertera pada lembar kerja siswa (LKS) guna memancing tanggapannya. Menggali serta mengeksplorasi pengetahuan awalnya, kemudian siswa membuat pertanyaan dan hipotesis dari gambar yang telah diamati (tahap elisitasi). Setalah itu, guru menunjukkan suatu gagasan yang kontradiktif dengan hasil eksplorasi siswa dengan memberikan sebuah pernyataan. Pernyataan tersebut dibuktikan dengan kegiatan praktikum dan dilanjutkan dengan penjelasan materi secara sistematis oleh guru guna membangun ulang kerangka konseptual siswa. Tahap terakhir, siswa mengaplikasikan konsep yang telah diperoleh dengan membuat hasil karya, yakni membuat paragraf mengenai pengalaman yang pernah siswa alami dalam kehidupan sehari-hari tentang materi larutan elektrolit dan nonelektrolit. Kelas yang diajar dengan model pembelajaran POE diawali dengan tahap predict. Yaitu siswa membuat sebuah pertanyaan dan memprediksikan jawabannya dengan cara membuat hipotesis (jawaban sementara) berdasarkan beberapa gambar yang siswa amati pada LKS. Tahap ini sama dengan tahap elisitasi pada model pembelajaran EKPA. Pada tahap ini siswa juga mengeksplorasi pengetahuan yang dimiliki. Untuk membuktikan hipotesis tersebut, siswa melakukan observasi atau pengamatan melalui kegiatan praktikum. Tahap terakhir, siswa melakukan diskusi kelompok mengenai hasil observasi dan mempresentasikannya di depan kelas.

Rata-rata hasil belajar kimia antara siswa yang diajar menggunakan model pembelajaran EKPA dan POE pada pokok bahasan elektrolit dan nonelektrolit tidak berbeda (tabel 1.).

Tabel 1

\begin{tabular}{|c|c|c|}
\hline Hasil b & $\begin{array}{r}\text { siswa sebe } \\
\text { perlaku: }\end{array}$ & an sesudah \\
\hline \multirow[b]{2}{*}{ Kelas } & \multicolumn{2}{|c|}{ Rata-rata hasil belajar siswa } \\
\hline & $\begin{array}{c}\text { Sebelum } \\
\text { perlakuan }\end{array}$ & $\begin{array}{c}\text { Sesudah } \\
\text { perlakuan }\end{array}$ \\
\hline $\mathrm{X} \mathrm{IPA}_{1}$ & $79,03^{\mathrm{a}}$ & $72,63^{a}$ \\
\hline $\mathrm{XIPA}_{2}$ & $78,96^{\mathrm{a}}$ & $72,07^{\mathrm{a}}$ \\
\hline
\end{tabular}

Huruf yang sama pada kolom yang sama menunjukkan tidak ada perbedaan

Fenomena ini dimungkinkan oleh persamaan landasan dalam kedua model pembelajaran ini. Model pembelajaran EKPA dan POE berlandaskan teori pembelajaran konstruktivisme yakni dengan menggali pengetahuan awal siswa dan kemudian siswa membuktikan kebenaran pengetahuan awalnya dengan eksperimen (An'nur, 2015; Fatonah dan Prasetyo, 2014). Konstruktivisme merupakan pendekatan dalam pembelajaran yang lebih menekankan pada tingkat kreativitas siswa dalam menyalurkan ide-ide baru yang dapat diperlukan bagi pengembangan dirinya yang didasarkan pada pengetahuan (An'nur, dkk., 2015). Pada kedua model pembelajaran ini, siswa diminta menggunakan pengetahuan awalnya dan memahami konsep materi (larutan elektrolit dan nonelektrolit). Tahap ini berlangsung pada fase elisitasi dalam model pembelajaran EKPA dan tahap predict dalam model pembelajaran POE. Siswa kemudian mengkonfirmasi pengetahuan yang dimilikinya dengan eksperimen, dimana pada tahap ini siswa melakukan penyesuaian antara pengetahuan awal dan pengetahuan yang baru didapatkan (Ma'rifatun, 2016). Tahap ini berlangsung pada fase konfrontasi dalam model pembelajaran EKPA dan tahap observe dalam model pembelajaran POE (Fatonah dan Prasetyo, 2014; Ma'rifatun, 2016). Melalui kegiatan elisitasi, konfrontasi, pengembangan konsep, dan aplikasi konsep dalam model pembelajaran EKPA dan kegiatan prediksi, observasi, dan menjelaskan hasil pengamatan dalam model pembelajaran POE, siswa menciptakan suasana pembelajaran yang terpusat pada dirinya, dimana peran guru adalah membantu siswa dalam menemukan fakta, konsep atau prinsip (Fatonah dan Prasetyo, 2014; Ma'rifatun, 2016). Kondisi tersebut membentuk struktur kognitif siswa dengan baik (An' nur, dkk., 2015). Melalui kegiatan secara mandiri tersebut, pengetahuan yang diperoleh siswa dapat diingat, dipahami, dan bisa terserap dengan sangat baik (An'nur, 2015).

\section{SIMPULAN}

Berdasarkan hasil penelitian, dapat disimpulkan bahwa tidak terdapat perbedaan antara hasil belajar siswa yang diajar dengan menggunakan model pembelajaran EKPA dan model pembelajaran POE pada sub pokok bahasan larutan elektrolit dan nonelektrolit.

\section{UCAPAN TERIMA KASIH}

Penulis mengucapkan terima kasih kepada kepala SMA Negeri 9 Samarinda yang telah memberikan izin penulis dalam melakukan penelitian ini. 


\section{DAFTAR PUSTAKA}

An' nur, S., Misbah, \& Noor, A. F. (2015). Perbedaan hasil belajar antara yang menggunakan model pembelajaran POE (prediction observation explanation) dan EIA (exploration introduction application) pada siswa kelas XI IPA SMA Negeri 4 Banjarmasin. Jurnal Inovasi dan Pembelajaran Fisika, 2(2), pp. 185193.

Fatonah, S., \& Prasetyo, Z. K. (2014). Pembelajaran sains. Yogyakarta: Penerbit Ombak.

Farikha, L. I. (2015). Penerapan model pembelajaran Predict observe explain (POE) disertai ekperimen pada materi pokok hidrolisis garam untuk meningkatkan aktivitas dan prestasi belajar siswa kelas XI MIA 3 SMA Negeri 4 Surakarta tahun pembelajaran 2014/2015. Jurnal Pendidikan Kimia (JPK), 4(4), pp. 95-102.

Lestari, N. N. S. (2012). Pengaruh model pembelajaran berbasis masalah (problem based learning) dan motivasi belajar terhadap prestasi belajar fisika bagi siswa kelas VII SMP. Jurnal Penelitian Pascasarjana Undiksha, 1(2), pp. 1-2.

Ma' rifatun, D., Martini, K. S., \& Utomo, S. B. (2014). Pengaruh model pembelajaran predict observe explaine (POE) menggunakan metode eksperimen dan demonstrasi terhadap prestasi belajar siswa pada pokok bahasan larutan penyangga kelas XI SMA al-islam 1 Surakarta Tahun Pelajaran 2013/2014, Jurnal Pendidikan Kimia (JPK), 3(3), pp. 11-16.

Nurachman, A. (2014). Pengaruh model pembelajaran EKPA terhadap hasil belajar pada pembelajaran tematik. Skripsi. Tasikmalaya: Universitas Pendidikan Indonesia.

Riyanto, B. (2011). Meningkatkan kemampuan penalaran dan prestasi matematika dengan pendekatan konstruktivisme pada siswa sekolah menegah atas. Jurnal Pendidikan Matematika, 5(2), pp. 111-128. 